\title{
Cacimod
}

\section{Good Practices in Watershed Management Lessons Learned in the Mid Hills of Nepal}

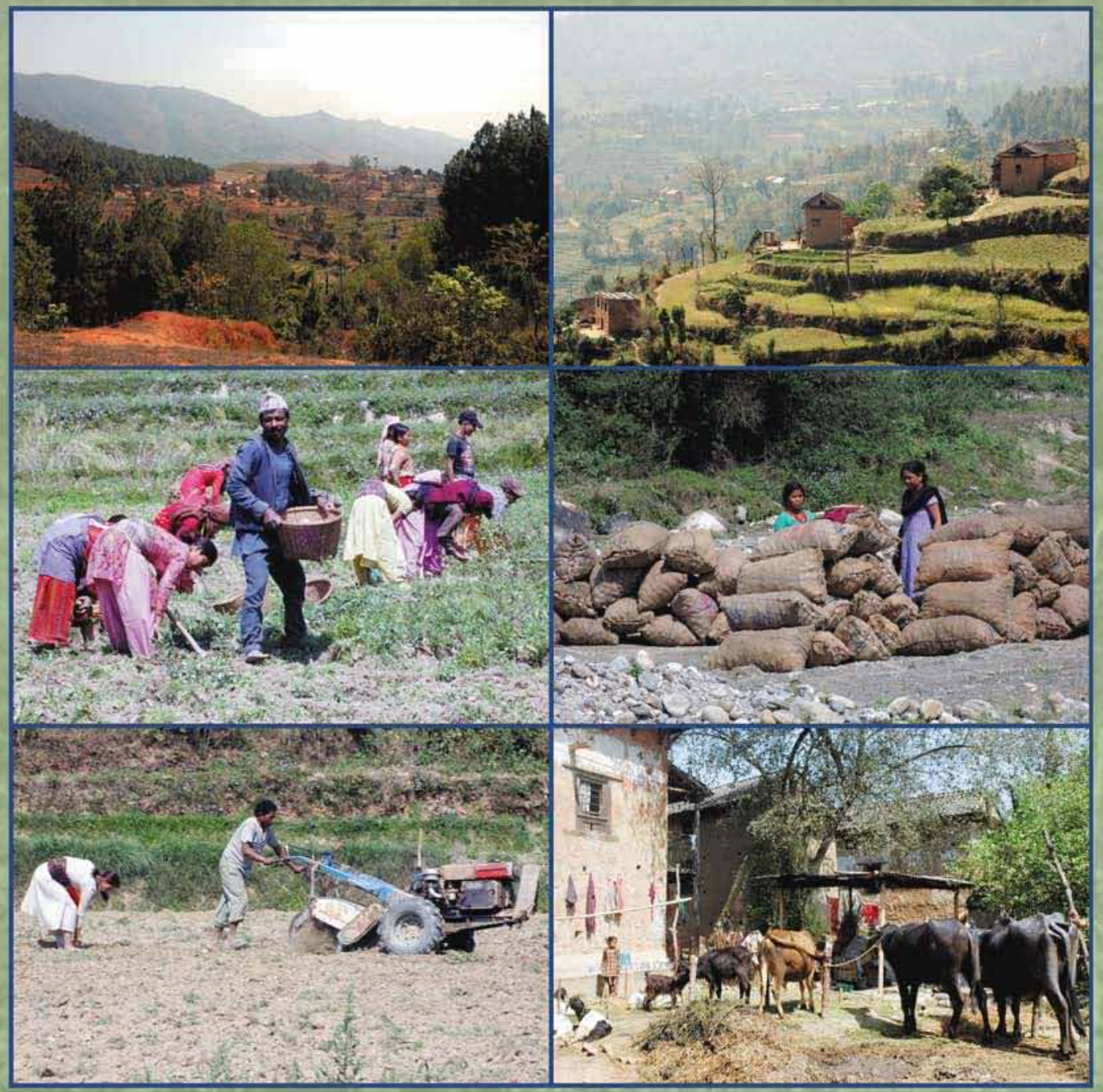




\section{About ICIMOD}

The International Centre for Integrated Mountain Development (ICIMOD) is an independent 'Mountain Learning and Knowledge Centre' serving the eight countries of the Hindu Kush-Himalayas - Afghanistan a-, Bangladesh

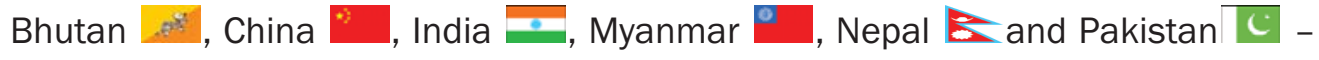
and the global mountain community. Founded in 1983, ICIMOD is based in Kathmandu, Nepal, and brings together a partnership of regional member countries, partner institutions, and donors with a commitment for development action to secure a better future for the people and environment of the extended Himalayan region. ICIMOD's activities are supported by its core programme donors: the governments of Austria, Denmark, Germany, Netherlands, Norway, Switzerland, and its regional member countries, along with over thirty project co-financing donors. The primary objective of the Centre is to promote the development of an economically and environmentally sound mountain ecosystem and to improve the living standards of mountain populations. 


\section{Good Practices in Watershed Management Lessons Learned in the Mid Hills of Nepal}

People and Resource Dynamics Project - Nepal Team 


\section{Copyright (c) 2007}

International Centre for Integrated Mountain Development (ICIMOD)

All rights reserved

\section{Published by the}

International Centre for Integrated Mountain Development

G.P.O. Box 3226

Kathmandu, Nepal

\section{ISBN 9789291150175}

\section{Editorial Team}

Matthew Zalichin (Consultant Editor)

A. Beatrice Murray (Senior Editor)

Dharma R. Maharjan (Technical Support; and Design Layout)

\section{Photo credits}

All photos from PARDYP Nepal

\section{Printed and bound in Nepal by}

Quality Printers (Pvt) Ltd.

Kathmandu

\section{Reproduction}

This publication may be reproduced in whole or in part and in any form for educational or non-profit purposes without special permission from the copyright holder, provided acknowledgement of the source is made. ICIMOD would appreciate receiving a copy of any publication that uses this publication as a source.

No use of this publication may be made for resale or for any other commercial purpose whatsoever without prior permission in writing from ICIMOD.

\section{Note}

The views and interpretations in this publication are those of the author(s). They are not attributable to ICIMOD and do not imply the expression of any opinion concerning the legal status of any country, territory, city or area of its authorities, or concerning the delimitation of its frontiers or boundaries, or the endorsement of any product. 


\section{The PARDYP Nepal Team}

\begin{tabular}{ll} 
Anil Shrestha & Sociologist \\
Bandana Prajapati & On-farm coordinator \\
Bhawani S. Dongol & Research Associate \\
Bhuban Shrestha & Country Coordinator \\
Birendra Raj Adhikari & Hydro-meteorologist \\
Diwakar Maskey & Social Forester \\
Gopal Nakarmi & Geologist \\
Juerg Merz & Hydrologist \\
Keshar Man Sthapit & Country Coordinator \\
Madhav P. Dhakal & Research Associate \\
Madhav Pandey & Social Forester \\
Megh Rajani Rai & Sociologist \\
Prabhakar Bickram Shah & Country Coordinator \\
Pradeep Man Dangol & Research Associate \\
Prem Raj Neupane & Agronomist \\
Radha Karki & Social Forester \\
Smita Shrestha & Water Management Assistant \\
Yamuna Ghale & Agronomist \\
\hline
\end{tabular}




\section{Contents}

Foreword

vii

Acknowledgements viii

Executive Summary ix

Acronyms and Abbreviations $\quad \mathrm{xi}$

1: INTRODUCTION

Background 1

Brief Description of the Watersheds 3

2: SOIL LOSS AND RUNOFF 9

Background 9

Soil Loss and Runoff Monitoring $\quad 10$

$\begin{array}{ll}\text { Farmer's Perceptions } & 15\end{array}$

Farm Management 16

Lessons Learned and Recommendations $\quad 17$

3: WATER SCARCITY 19

$\begin{array}{ll}\text { Background } & 19\end{array}$

Water Demand and Supply 20

Management Options $\quad 24$

Lessons Learned and Recommendations 34

4: WATER QUALITY 37

Background $\quad 37$

Water Quality Monitoring $\quad 37$

Water Quality Improvement Options 38

Lessons Learned and Recommendations $\quad 40$

5: ON FARM 41

How Can Farmers Maintain or Improve Soil Fertility? 41

Leachate Study in the Jhikhu Khola Watershed 44

How to Rehabilitate Degraded Land 45

How Can We Increase Farm Income? 49

What Approaches Can be Used to Build the Capacity of Communities? 51

How to Reduce Workloads, Especially of Women 54

Lessons Learned and Recommendations 56 
What are Feasible Local Rules and Practices for Ensuring Equitable Access to Natural Resources?

Access to Institutions and Information $\quad 62$

Access to Natural Resources $\quad 62$

Decision-making for Different Activities $\quad 66$

$\begin{array}{ll}\text { Lessons Learned and Recommendations } & 67\end{array}$

\section{7: BIBLIOGRAPHY AND FURTHER READING}

\section{ANNEXES (on CD-ROM in back pocket)}

Annex 1: Rainfall of the Jhikhu and Yarsha Khola Watersheds

Annex 2. Rainfall of the Yarsha Khola Watershed

Annex 3: Description of the Soil Loss and Runoff Plots

Annex 4: Soil Loss, Runoff, and Rainfall in the Jhikhu Khola Watershed

Annex 5. Soil Loss, Runoff, and Rainfall in the Yarsha Kola Watershed

Annex 6. Crop Water Requirement Analysis

Annex 7. Rainfall Analysis

Annex 8: Barabot Spring in Dhotra, Jhikhu Khola Watershed

Annex 9. Roof Rainwater Harvesting Jars

Annex 10. Monitoring of the Water Table in Dug Wells of the Jhikhu Khola Watershed

Annex 11. Water Balance

Annex 12. PARDYP's Experience with the System of Rice Intensification

Annex 13. Changing Cropping Patterns

Annex 14. Water Quality Studies

Annex 15. Leachate Study in the Jhikhu Khola Watershed 


\section{Foreword}

The middle altitudes of the Himalayan region are intensively used and highly populated. The management of land, forest and water in these areas is the basis of mountain livelihoods. The land use practices employed depend on the complex dynamics of waterland relationships as well as the diverse social, institutional, and economic conditions found throughout the region. These practices have profound impacts on the productivity and sustainability of mountain watersheds as well as the millions living downstream.

The importance of understanding the dynamics and relationships between socioeconomic and biophysical aspects of middle altitude mountain watersheds led ICIMOD to amalgamate earlier projects on the rehabilitation of degraded land and mountain natural resources into the 'People and Resource Dynamics in Mountain Watersheds of the Hindu Kush-Himalayas' project (PARDYP) in 1996 based on experience in Nepal. The Swiss Agency for Development and Cooperation (SDC) joined the International Development Research Centre (IDRC, Canada) in providing funding and intellectual support.

PARDYP illustrates the collaborative regional approach taken by ICIMOD. Research and the daily management of project sites were undertaken by the collaborating focal institutions in China, India, Nepal, and Pakistan. The participating scientists from these countries were the project's researchers. Technical backstopping was provided by specialists from the Universities of British Columbia (Canada), Zurich and Berne (Switzerland).

This publication documents the experience and lessons learned from the PARDYP-Nepal sites. Detailed hydro-meteorological data, together with land use related data, were collected and analysed to increase understanding of topics such as land degradation and water management. The results have been archived for future research use on climate change, land use dynamics, and sustainable mountain agriculture and are partly presented here. Many of the easy-to-implement technological options for improved livelihoods and community-based management of natural resources developed by the project are relevant across the middle altitude zones of the Himalayan region and are also presented here. The document also addresses many of the questions commonly asked about managing mountain natural resources and forms the basis for developing the next generation of watershed management programmes.

I hope that the publication will be useful to extension workers, planners, development specialists, researchers, and policy makers in national institutions, NGOs, and donor agencies working on watershed management and mountain agriculture. I would like to extend my sincere gratitude to SDC, IDRC and ICIMOD core donors for their generous financial support. 


\section{Acknowledgements}

This report was written by a group of PARDYP-Nepal staff. Keshar Man Sthapit led the preparation. Pradeep Dangol contributed the chapter on 'Soil Loss and Runoff Monitoring'; Bhawani Dongol contributed the chapters on 'Water Scarcity and Water Quality'; Madhav Dhakal contributed the section on management options in the 'Water Scarcity' chapter, the 'On Farm' chapter, and the case studies in the 'Access' chapter; and Anil Shrestha contributed the institutions section of the 'Access' chapter.

Our heartfelt thanks go to all the station observers who took the hydro-meteorological measurements, the field staff involved in the supervision and implementation of the field activities, and the farmers involved in implementing the activities. Thanks also go to all the professional staff who served PARDYP in the many research studies and implementation of field activities, and all the students who carried out research in the watersheds in part fulfilment of their academic studies (B.Sc., M.Sc., and Ph.D.).

This document follows the format and questionnaires developed at a workshop with participants from three of the PARDYP country teams (India, Nepal, and Pakistan), the regional support team, and a technical backstopping team (from the University of Berne). Thanks go to all the members of these teams, especially Dr. Rolf Weingartner.

The support of different line agencies, especially the Department of Soil Conservation and Watershed Management, Spice Crop Development Centre, District Forest Office, District Agriculture Office, and Divisional Irrigation Office, is gratefully acknowledged.

Special thanks go to Roger White, Sanjeev Bhuchar, Isabelle Providoli and other ICIMOD staff for their thorough review and valuable suggestions, and to Eklabya Sharma for his support in preparing the document. Thanks to all participants at the 'Dissemination Workshop on Lessons Learned under PARDYP' held on 25 May 2006 at Dhulikhel, Kabhre District for their comments and suggestions, and especially Gregor Doppmann for his comments.

Last but not least, we thank the Publications Unit in the IMCO Division of ICIMOD for the preparation of the book in its final form.

People and Resource Dynamics Project-Nepal (PARDYP) ICIMOD, 2006 


\section{Executive Summary}

From September 1996 to June 2006, ICIMOD conducted research to investigate the dynamics and relationships between socioeconomic and natural resources' factors in five middle-mountain watersheds across the Himalayas (in China, India, Nepal, and Pakistan). The People and Resource Dynamics Project (PARDYP) in Mountain Watersheds of the Hindu Kush-Himalayas was funded by the Swiss Agency for Development and Cooperation (SDC) and the International Development Research Centre (IDRC).

The research focused on farming systems, agricultural productivity, water management and access, and equity issues in resource management for middle-mountain watershed areas of the region. It aimed to design future interventions, and to scale up the successes thus far achieved. This publications summarises the lessons learned and recommendations from the project activities in Nepal as follows.

- Erosion studies from Jhikhu and Yarsha Khola watersheds show that soil erosion from properly farmer managed agricultural land is much less than originally believed. However, erosion increases when the slope is more than $\mathbf{1 0}$ degrees. Most sedimentation originates from areas such as landslips, degraded slopes, roadsides, gullies, and stream banks. Peak runoff is generally observed during intense and high rainfall reaching daily amounts of $100 \mathrm{~mm}$ or more.

- Nutrient leaching is a far more important issue to farmers than farm soil erosion. In rainfed agricultural land, the leaching volume at $45 \mathrm{~cm}$ depth in the soil profile is significantly higher than surface runoff.

- Increasing demand for water. Upland communities are concerned about low flows during the pre- and post-monsoon seasons, which affect both irrigation and household needs. However, the data show that the low-flow problem is not due to reduced precipitation or water supply within the watershed, but mainly to increasing demand for water - both for irrigation and drinking - and to poor local water management.

- Improving water management. Some tested technological options include eyebrow pitting in degraded land for improving soil moisture, catchment conservation to improve water availability for drinking water, plastic lined conservation ponds to harvest surface water for irrigation, and harvesting roof-water for drinking purposes. Drip and sprinkler irrigation techniques and the System of Rice Intensification (SRI) are among other options tested for increasing the efficiency of water use.

- PARDYP's research on water quality shows that microbiological contamination of drinking water is severe and must be addressed through preventing contamination and improved treatment of both catchments and water sources.

- Forest area cover in the Jhikhu Khola watershed remained stable between 1972 and 1996. Forest density improved significantly during the same period mainly as a result of community forestry programmes that increased people's participation and ownership in the management of forests. The entire community forest area within 
the Jhikhu Khola watershed was mapped showing forest types, tree density, and maturity class. These maps helped the District Forest Office Kabhre in planning the community forestry programme in the watershed.

- Agriculture in the middle-mountain watersheds of the Himalayan region is intensifying and becoming more market oriented, especially in areas with irrigation facilities and links to markets. However, in order to sustain higher production levels, farmers are applying very high doses of pesticides and chemical fertilisers, which has a negative impact on ecosystems.

- Black plastic composting with the use of effective micro-organisms has enhanced the decomposition process and produced better fertiliser to address soil-nutrient needs.

- The challenge in the middle mountain watersheds is to increase the income of smallholder farmers, especially those cultivating rainfed land. Low levels of production and small landholdings are pushing young farmers to migrate to urban/semi-urban areas.

- Issues of poor access, equity, and governance are still of concern and need proper attention. The workload for mountain women remains higher than for men throughout the year, especially in fetching water, collecting fodder and fuelwood, and household work. In the Jhikhu Khola watershed, women typically work 3.8 hours longer per day than men, and $68 \%$ of water fetching is done by women. Roofwater harvesting saved women up to 27 minutes on average for each trip to fetch water in the Jhikhu Khola watershed. Similarly, fodder development on their private land can save women 60 to 90 minutes per day for fodder collection.

- Dissemination and scaling up of the lessons is a major challenge. Sharing of messages (success and failure stories) among villages through exchange visits, onsite training camps, farmer field schools, national workshops, farmer days, and similar, has been very effective. In addition, participatory action research proved to be effective in testing new technologies together with farmers. This approach strengthened farmers' behaviour to be research oriented in other areas, which is essential for improving livelihoods. 


\section{Acronyms and Abbreviations}

$\begin{array}{ll}\text { DAP } & \text { diammonium phosphate } \\ \text { DDC } & \text { district development committee } \\ \text { DSCWM } & \text { Department of Soil Conservation and Watershed Management } \\ \text { EC } & \text { electrical conductivity } \\ \text { EEC } & \text { European Economic Commission } \\ \text { EM } & \text { effective microorganisms } \\ \text { GOs } & \text { government offices } \\ \text { ICIMOD } & \text { International Centre for Integrated Mountain Development } \\ \text { IDRC } & \text { International Development Research Centre } \\ \text { NGO } & \text { non-government organisation } \\ \text { NRS } & \text { Nepalese rupees } \\ \text { NTU } & \text { nephelometric turbidity unit } \\ \text { PARDYP } & \text { People and Resource Dynamics Project } \\ \text { RWSSSP } & \text { Rural Water Supply and Sanitation Support Programme } \\ \text { SCDC } & \text { Spice Crop Development Centre } \\ \text { SDC } & \text { Swiss Agency for Development and Cooperation } \\ \text { SODIS } & \text { solar water disinfection } \\ \text { SRI } & \text { System of Rice Intensification } \\ \text { USD } & \text { United States dollar } \\ \text { VDC } & \text { village development committee }\end{array}$

\section{Currency Equivalent}

In this report all references to rupees (Rs) are to Nepalese rupees

Currency Unit - Nepalese rupees (NRs)

$\$ 1=$ NRs 56.75 (as of December 1996)

$\$ 1=$ NRs 71.40 (as of December 2006)

\section{Notes}

(i) The Nepalese calendar year (B.S.) runs from mid April to mid April. Unless otherwise stated, year ranges written in the form 2005/06 denote a single calendar year.

(ii) In this report, \$ refers to US dollars.

(iii) In this report, tons (t) refer to metric tons or tonnes $(1,000 \mathrm{~kg})$. 
